\title{
Shear capacity of reinforced concrete beams strengthened with web side bonded CFRP sheets
}

\author{
Rendy Thamrin*, Zaidir, and Sabril Haris \\ Civil Engineering Department, Engineering Faculty, Andalas University, 25163 Padang, Indonesia
}

\begin{abstract}
The shear capacity of reinforced concrete beams strengthened with web side bonded carbon fiber-reinforced polymer (CFRP) sheets was measured experimentally. Nine reinforced concrete beams without stirrups; three control beams and six beams strengthened with minimal application of web side bonded CFRP sheets, were tested. The test variables were ratio of longitudinal reinforcement $(1 \%, 1.4 \%$, and $2.4 \%)$ and angle of application of CFRP sheets $\left(45^{\circ}\right.$ and $\left.90^{\circ}\right)$. The test results show that reinforced concrete beams strengthened with web side bonded CFRP sheets have higher shear capacity compared to the control beams. Shear capacity of strengthened beams with $45^{0}$ angle of application of CFRP sheets is similar to that of beams strengthened with $90^{\circ}$ angles. Beams with $1 \%$ of longitudinal reinforcement ratio failed in flexural mode indicated by concrete crushing in compression zone while beams with higher longitudinal reinforcement ratio $(1.4 \%$ and $2.4 \%)$ failed in brittle mode as indicated by delamination of the concrete cover.
\end{abstract}

\section{Introduction}

In the last decade, Fibre Reinforced Polymer (FRP) sheets have become popular as strengthening materials for damaged reinforced concrete structures. FRP sheets have several advantages such as high tensile strength, fast transport and site installation as a consequence of their low weight, and corrosion resistance.

Research reports on the application of fiberreinforced polymers began to be published in 1971 [1] and a large number of studies have been reported in recent years due to the need for new materials to retrofit structures, high-performance FRP materials and rapid development of FRP technology in the chemical industry [3-12]. Khalifa et al. [3] showed that strengthening using CFRP sheets increased the shear capacity of reinforced concrete beams. This phenomenon has also been reported by others $[4,6,10]$. However, debond of CFRP sheets from the strengthened beams due to high shear stress and occurrence of diagonal shear crack has been identified as the major problem for this strengthening system [10-11]. Bukhari et al. [7] found that fiber orientation affects the ability of CFRP sheets to support shear forces.

Codes and design guidelines have also been established for FRP sheets applications based on past research results. The most recent code published by the American Concrete Institute for the application of FRP materials to strengthen the concrete structure is $\mathrm{ACI}$ 440.2R-17 [2]. As is stated in ACI 440.2R-17 there are several common wrapping methods and fiber orientation used for shear strengthening using FRP sheets as illustrated in Figs. 1 and 2.
Although many research reports related to the application of FRP materials are available, limited information is available regarding behavior associated with shear failure and the minimal application of CFRP sheets needed to strengthen reinforced concrete members against shear forces. Therefore, further research related to shear retrofitting is important.

This paper presents the results of an experimental study on shear capacity of reinforced concrete beams without stirrups strengthened using Carbon Fiber Reinforced Polymer (CFRP) sheets. A minimal application of CFRP sheets at two different angles of application and three ratios of longitudinal reinforcements were used as the test variables. The wrapping was bonded to the two opposing web sides of the beam.

\section{Experimental study}

A total of nine reinforced concrete beams without stirrups were tested. The test variables were the angles of application of CFRP sheets either vertical $\left(90^{\circ}\right)$ or diagonal $\left(45^{\circ}\right)$ and the ratios of longitudinal reinforcements $(1 \%, 1.4 \%$, and $2.4 \%)$. The tested beam specimens used in this study are shown in Fig. 3. The beam dimensions were $125 \mathrm{~mm}$ width, $250 \mathrm{~mm}$ depth, and $2300 \mathrm{~mm}$ span length. The tension longitudinal reinforcement was $13 \mathrm{~mm}$ diameter deformed steel bars with $448 \mathrm{MPa}$ yield strength and the compression longitudinal reinforcement was $10 \mathrm{~mm}$ diameter deformed steel bars with $355 \mathrm{MPa}$ yield strength and modulus of elasticity $200 \mathrm{GPa}$. 


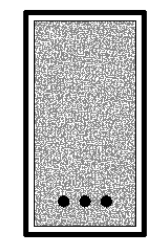

Completely wrapped

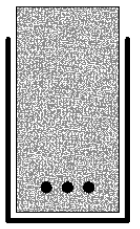

3-sided

"U-wrap"

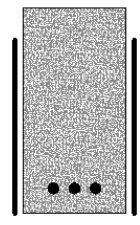

2 sides
Fig. 1. Common wrapping methods for shear strengthening using FRP sheets [2].

Fresh concrete was ordered from a ready-mix concrete company. The maximum aggregate size of concrete was $10 \mathrm{~mm}$. The concrete compressive strength was determined using the standard test for compressive strength of cylindrical specimens [13] and the concrete compressive strength at age 28 days was found to be 20 MPa. CFRP sheets were supplied by PT. Fyfe Fibrwrap Indonesia. The design tensile strength of CFRP sheets was $690 \mathrm{MPa}$ with a modulus of elasticity of 745500 $\mathrm{MPa}$. Table 1 shows more details of the properties of the material and specimen beams.

Installation of CFRP sheets was carried out by a certified applicator as shown in Fig. 4. The concrete surface was first ground smooth using an electric grinder. Then, the pores on the concrete surface were filled with special chemical filler. Adhesive liquid then was applied with a special roller on the concrete surface and the CFRP sheets. The last step of the process was placing CFRP sheets on the surface of the web sides. The testing was carried out seven days after installation of CFRP sheets.
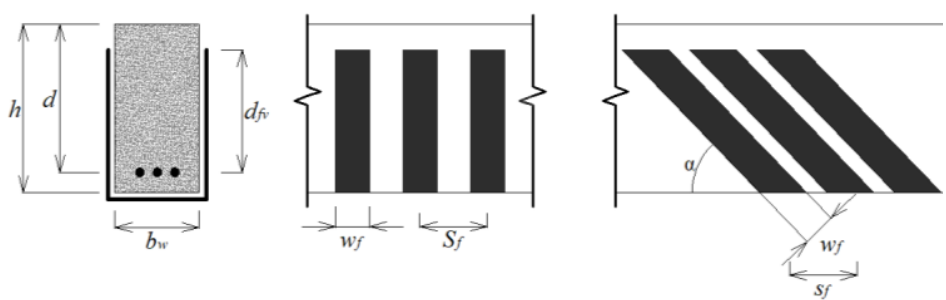

Fig. 2. Notation of variables used in shear strengthening using FRP sheets according to ACI 440.2R-17 [2].

During the test, the load was applied gradually until failure using a hydraulic jack with $500 \mathrm{kN}$ capacity. At each level of the applied load, the values of load and deflection at the middle of the beam and at the load points were measured using a load cell and transducer connected to a data logger. The cracks occurring during the test were also visually observed at each level of the applied load.

\section{Theoretical Beam Capacities}

\subsection{Flexural capacity}

The theoretical flexural capacity of the tested beam specimens was calculated based on theoretical momentcurvature analysis $[14,15]$. The cross-section is divided into a finite number of concrete and reinforcement layers and response of layers of each incremental load is analyzed using a computer program called Reinforced Concrete Cross Section Analysis (RCCSA). (a) Control beams.

(b) Vertical application of CFRP sheets. (c) Diagonal application of CFRP sheets.
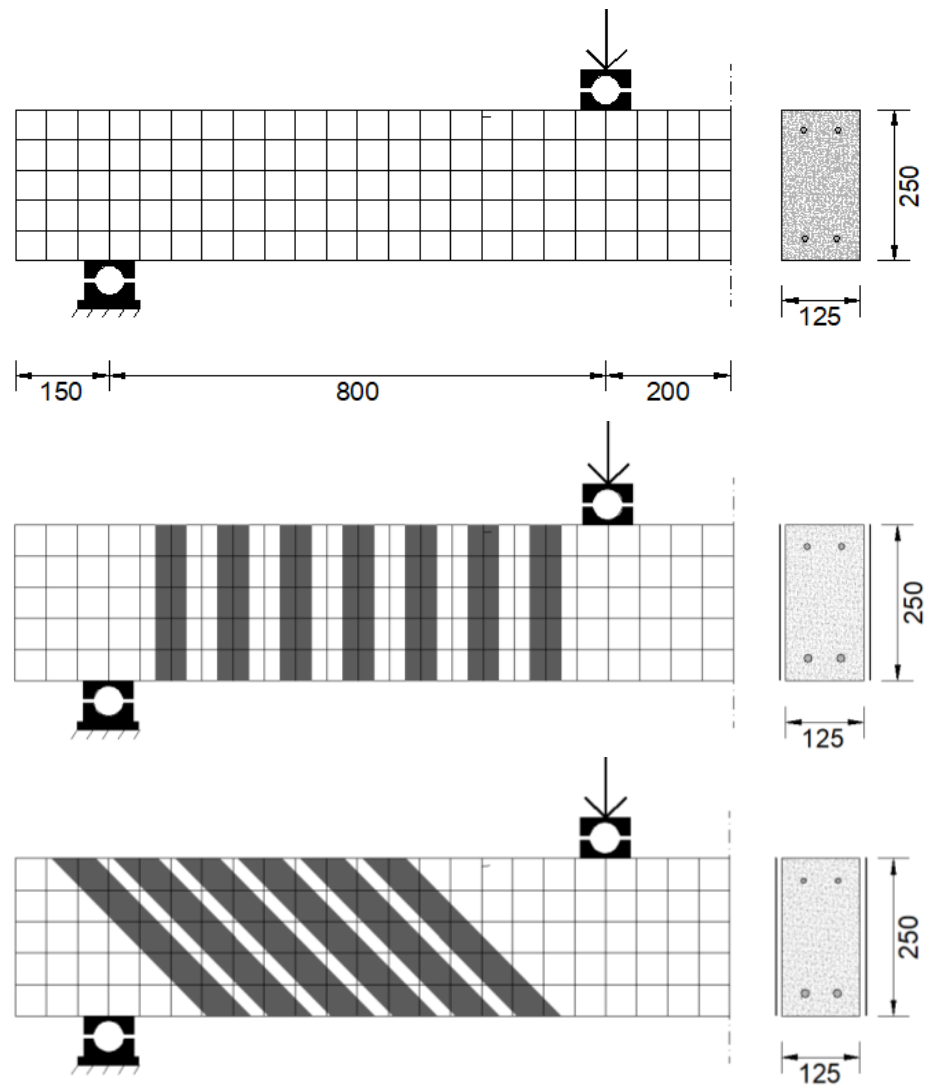

Fig. 3. Dimensions, loading position, and wrapping schemes of the tested beams. 
Table 1. Beam details and capacities.

\begin{tabular}{|c|c|c|c|c|c|c|c|c|c|c|c|c|c|c|c|c|c|c|c|}
\hline \multirow{3}{*}{ Specimens } & \multicolumn{7}{|c|}{ Shear Strengthening (CFRP) } & \multicolumn{3}{|c|}{$\begin{array}{l}\text { Longitudinal } \\
\text { Reinforcement } \\
\text { (Tension) }\end{array}$} & \multicolumn{3}{|c|}{$\begin{array}{l}\text { Longitudinal } \\
\text { Reinforcement } \\
\text { (Compression) }\end{array}$} & \multicolumn{2}{|c|}{ ACI $318-14$} & \multicolumn{2}{|c|}{ ACI $440.2 R-18$} & \multirow{2}{*}{\begin{tabular}{|c}
$\begin{array}{c}\text { Exp. } \\
\text { Shear } \\
\text { Strength }\end{array}$ \\
Vu exp.
\end{tabular}} & \multirow{2}{*}{$\begin{array}{c}\text { Calc. } \\
\text { Flexural } \\
\text { Capacity } \\
V b\end{array}$} \\
\hline & \multirow{2}{*}{$s_{f}(\mathrm{~mm})$} & \multirow{2}{*}{$t_{f}(\mathrm{~mm})$} & \multirow{2}{*}{$w_{f}(\mathrm{~mm})$} & \multirow[b]{2}{*}{$n$} & \multirow{2}{*}{$\begin{array}{c}A_{f v} \\
\left(\mathrm{~mm}^{2}\right)\end{array}$} & \multirow{2}{*}{$\begin{array}{c}d_{f v} \\
(\mathrm{~mm})\end{array}$} & \multirow{2}{*}{$\alpha$} & \multirow{2}{*}{$\mathrm{N}$} & \multirow{2}{*}{$\begin{array}{c}d_{b} \\
(\mathrm{~mm})\end{array}$} & \multirow{2}{*}{$\rho(\%)$} & \multirow{2}{*}{$\mathrm{N}$} & \multirow{2}{*}{$\begin{array}{c}d_{b} \\
(\mathrm{~mm})\end{array}$} & \multirow{2}{*}{$\rho^{\prime}(\%)$} & $V c$ & Vs & $V f$ & $V n$ & & \\
\hline & & & & & & & & & & & & & & $(\mathrm{kN})$ & $(\mathrm{kN})$ & $(\mathrm{kN})$ & $(\mathrm{kN})$ & $(\mathrm{kN})$ & $(\mathrm{kN})$ \\
\hline BCS-01 & & & & \multirow{3}{*}{\multicolumn{4}{|c|}{-}} & 2 & \multirow{9}{*}{13.0} & 1.0 & \multirow{9}{*}{2} & \multirow{9}{*}{10.0} & \multirow{9}{*}{0.6} & \multirow{9}{*}{20.5} & \multirow{9}{*}{0.0} & \multirow{3}{*}{-} & 15.4 & 22.2 & 30 \\
\hline BCS-02 & & & & & & & & 3 & & 1.4 & & & & & & & 15.4 & 24.4 & 43 \\
\hline BCS-03 & & & & & & & & 5 & & 2.4 & & & & & & & 15.4 & 26.4 & 58 \\
\hline BS-01V & 100.0 & 0.6 & 50.0 & 1.0 & 60.0 & 220.0 & 90.0 & 2 & & 1.0 & & & & & & 19 & 27.7 & 34.7 & 30 \\
\hline BS-02V & 100.0 & 0.6 & 50.0 & 1.0 & 60.0 & 220.0 & 90.0 & 3 & & 1.4 & & & & & & 19 & 27.7 & 43.5 & 43 \\
\hline BS-03V & 100.0 & 0.6 & 50.0 & 1.0 & 60.0 & 220.0 & 90.0 & 5 & & 2.4 & & & & & & 19 & 27.7 & 56.4 & 58 \\
\hline BS-01D & 100.0 & 0.6 & 50.0 & 1.0 & 60.0 & 220.0 & 45.0 & 2 & & 1.0 & & & & & & 28 & 33.0 & 35.9 & 30 \\
\hline BS-02D & 100.0 & 0.6 & 50.0 & 1.0 & 60.0 & 220.0 & 45.0 & 3 & & 1.4 & & & & & & 28 & 33.0 & 44.2 & 43 \\
\hline BS-03D & 100.0 & 0.6 & 50.0 & 1.0 & 60.0 & 220.0 & 45.0 & 5 & & 2.4 & & & & & & 28 & 33.0 & 58.3 & 58 \\
\hline
\end{tabular}
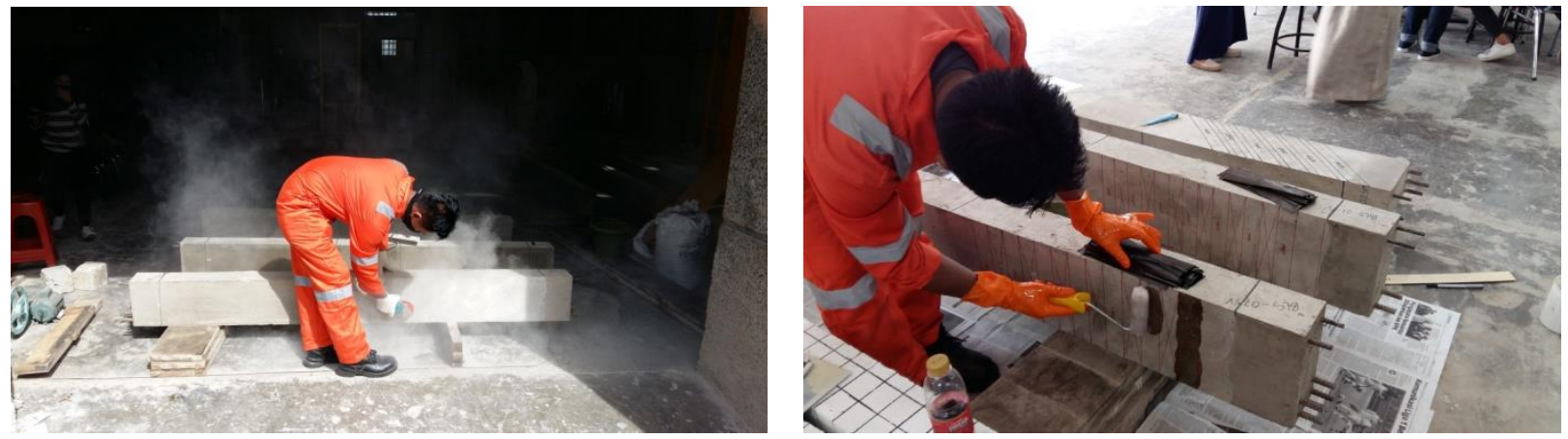

Fig. 4. The installation process of CFRP sheets by a certified applicator.

The strain distribution for each incremental load is obtained using a given value of curvature. The stressstrain law of concrete used in the calculation process is obtained from literature [16]. The maximum strain value of concrete in compression is assumed to be 0.003 . The tensile stress-strain law of concrete used is linear up to the maximum tensile strength. The concrete tensile strength was taken as $10 \%$ of the concrete compressive strength. The stress-strain law for steel reinforcement applied in this study is bi-linear. Equilibrium of internal forces in cross-section for each incremental load step is obtained using an iterative procedure. After equilibrium of internal forces at each load step is satisfied, the moment-curvature relationship can be attained and the load-deflection curve can be obtained from the momentcurvature relationship.

\subsection{Shear capacity}

Theoretical nominal shear strength provided by concrete for each of the specimens was obtained using the equation provided by ACI $318 \mathrm{M}-14$ [17] as:

$$
V_{c}=0.172 \lambda \sqrt{f_{c}^{\prime}} b_{w} d
$$

Theoretical nominal shear strength contributed by CFRP sheets is adopted from ACI 440.2R-17 [2] as:

$$
V_{f}=\frac{A_{f} f_{f c}(\sin \alpha+\cos \alpha) d_{f v}}{s_{f}}
$$

where $A_{f}=2 n t_{f} w_{f}$

$$
\phi V_{n}=\phi\left(V_{c}+V_{s}+\psi_{f} V_{f}\right)
$$

where: $f_{c}^{\prime}$ is the concrete compressive strength, $\lambda$ is the modification factor to reflect the reduced mechanical properties of lightweight concrete relative to normal weight concrete of the same compressive strength, $b_{w}$ is the width of the web of rectangular cross section, $d$ is the effective depth, $A_{f}$ is the area of FRP external reinforcement, $f_{f c}$ is the effective stress in FRP, $\alpha$ is the angle of application of FRP reinforcement direction, $d_{f v}$ the effective depth of FRP shear reinforcement, $s_{f}$ is the centre-to-centre spacing of FRP strips, $n$ is the number of plies in the FRP sheets (in this study this parameter is equal to one), $t_{f}$ is the nominal thickness of one ply of FRP sheets, and $w_{f}$ is the width of FRP sheets. The test results and the calculated theoretical flexural and shear capacities of the beams are listed in Table 1.

\section{Test results and discussion}

\subsection{Beam Capacity}

Shear force versus mid-span deflection curves for all of the tested beams are shown in Fig. 5. Sudden failure of all control beams is caused by formation of diagonal shear cracks in the shear span zone as expected. This diagonal shear crack developed at maximum tensile strength with an average load value of $24 \mathrm{kN}$. This value is higher than the predicted nominal shear strength provided by concrete calculated using equation (1). This indicates that the shear strength estimation provided by this equation is conservative. The shear strength contribution of CFRP sheets calculated using equation (4) also indicates that the prediction provided by this equation is conservative (as listed in Table 1). 


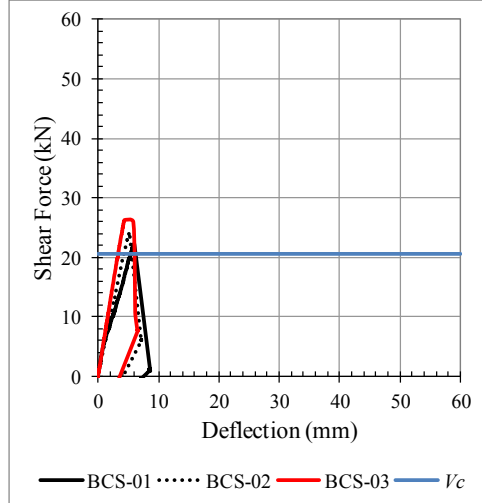

(a) Control beams.

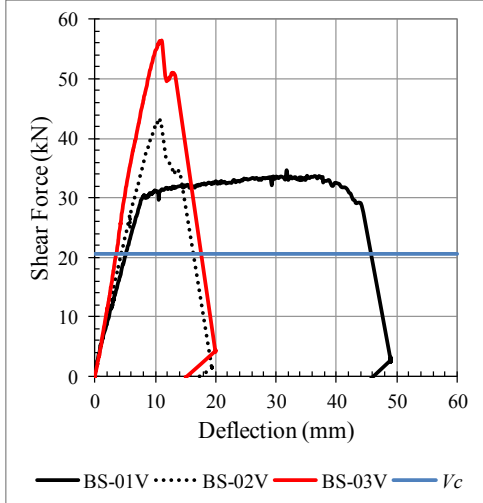

(b) Vertical application of CFRP sheets.

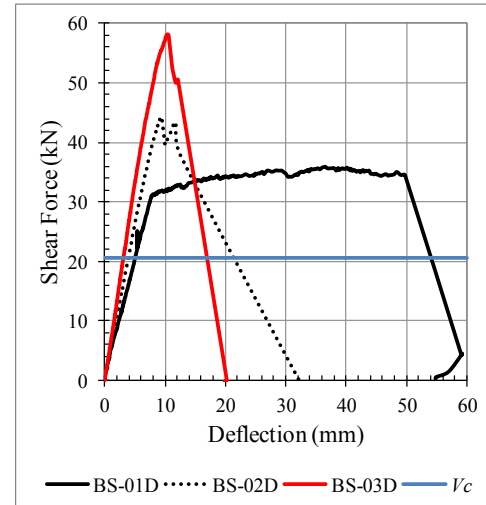

(c) Diagonal application of CFRP sheets

Fig. 5. Comparison of load-deflection curves for beams with different ratio of longitudinal reinforcement. $V_{c}$ is the theoretically calculated nominal shear strength provided by concrete.

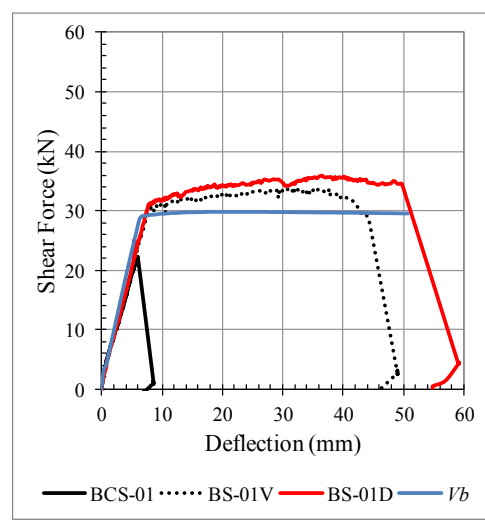

(a) Reinforcement ratio $1.0 \%$.

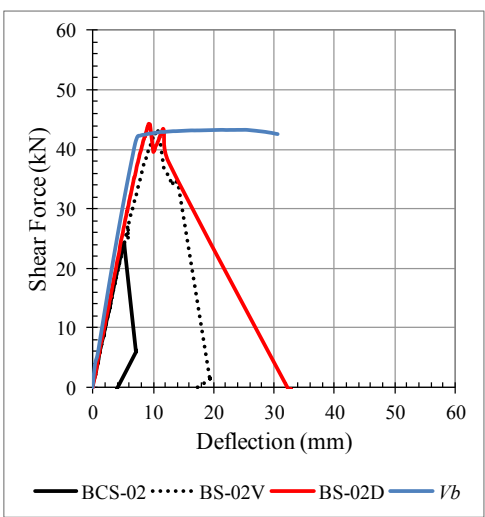

(b) Reinforcement ratio $1.4 \%$.

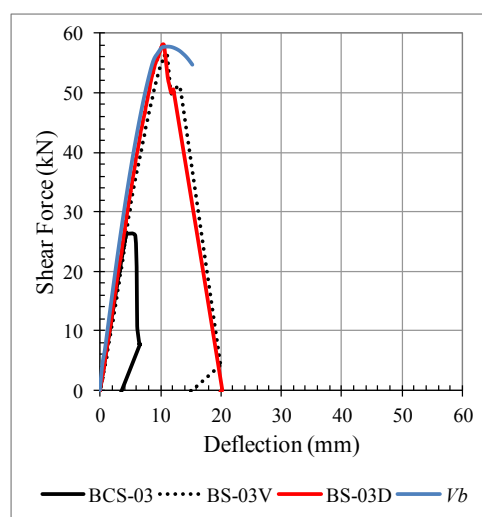

(c) Reinforcement ratio $2.4 \%$.

Fig. 6. Effect of CFRP strengthening on shear capacity and comparison between analytical predictions with the test results. Flexural capacity $\left(V_{b}\right)$ is the theoretical flexural capacity based on moment-curvature analysis.

Theoretical flexural capacities and experimental shear strength of the tested beams are shown in Fig. 6. It is shown in Fig. 6 that CFRP sheets significantly increase the shear capacity of the beams. However, none of the strengthened beams reached the ultimate flexural strength due to debonding of CFRP sheets as is indicated by the sudden drop in the experimental load-deflection curves. Even though curves for BS-01D and BS-01V indicate yielding of tensile longitudinal reinforcement, as also in agreement with the load-deflection curve obtained from flexural analysis, these two beams exhibited debonding failure before they reached the theoretical ultimate flexural strength.

\subsection{Crack Patterns}

Schematic representations of crack patterns of the tested beams are illustrated in Fig. 7. The diagonal shear cracks in the shear span zone caused the shear failure of the control beams. Also, the constant moment zone of the strengthened beams is severely cracked due to the installation of CFRP sheets in the shear span zone. This indicates that the installation of CFRP sheets significantly changed the crack patterns of the beams.

Fig. 8 shows parts of the strengthened beams after the occurrence of debonding failure. It is shown that debonding failure for all cases of the tested beams accompanied by concrete cover separation occurred in the shear span zone near to the loading point.

\section{Conclusions}

The following conclusions can be drawn from the test:

1. It was observed from the test that even with minimum application the installation of CFRP sheets increases the beam capacity significantly.

2. Debonding failure for all cases of the tested beams accompanied by concrete cover separation occurred in the shear span zone near to the loading point.

3. Theoretical shear strength contribution of CFRP sheets calculated using ACI 440.2R-17's equation indicates that the equation is conservative.

4. Three sided or completely wrap application of CFRP sheets may be necessary to prevent premature debonding failure for beams with higher values of longitudinal reinforcement ratio.

The author would like to thank PT. Fyfe Fibrewrap Indonesia for material support and installation of CFRP sheets. The author would also like to thank LPPM of Andalas University for the research fund support through Penelitian Skim Klaster Riset Guru Besar with contract number 22/ UN.16.17 / PP.RGBL / LPPM / 2018 in the financial year 2018. 
(a) BCS-01

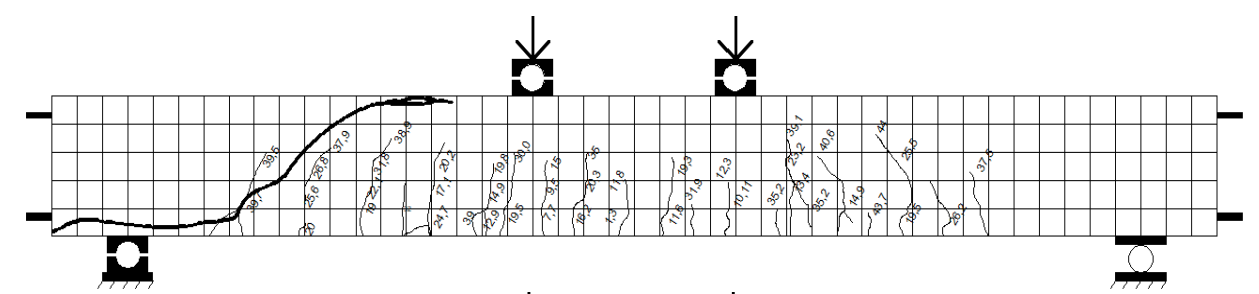

(b) BCS-02

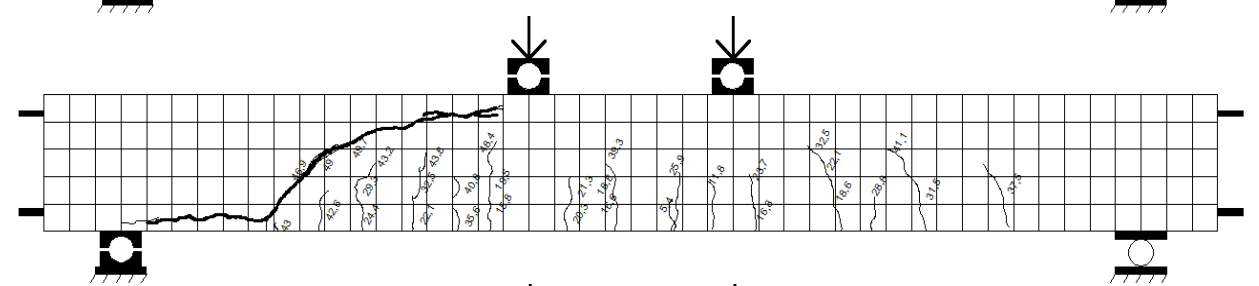

(c) BCS-03

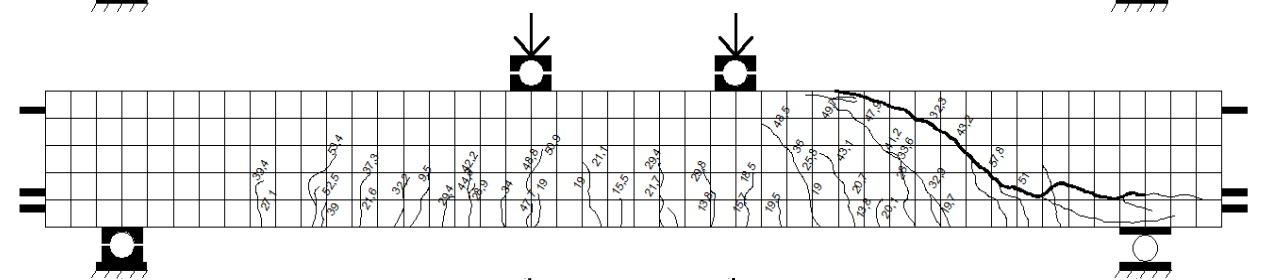

(d) BS-01V

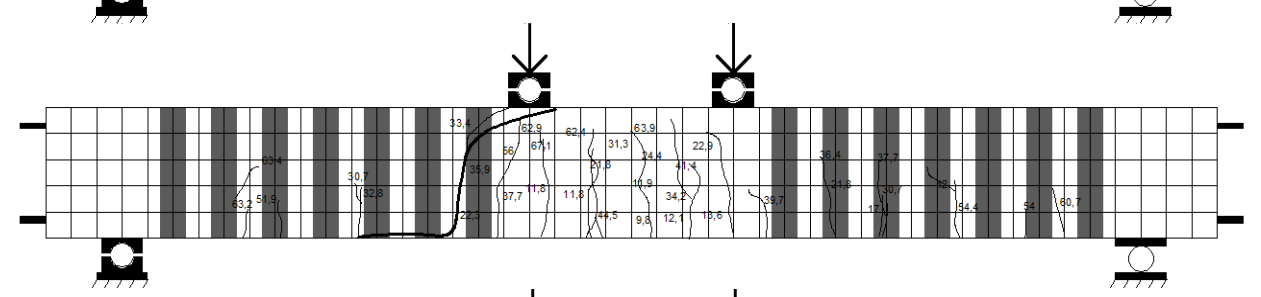

(e) BS-02V

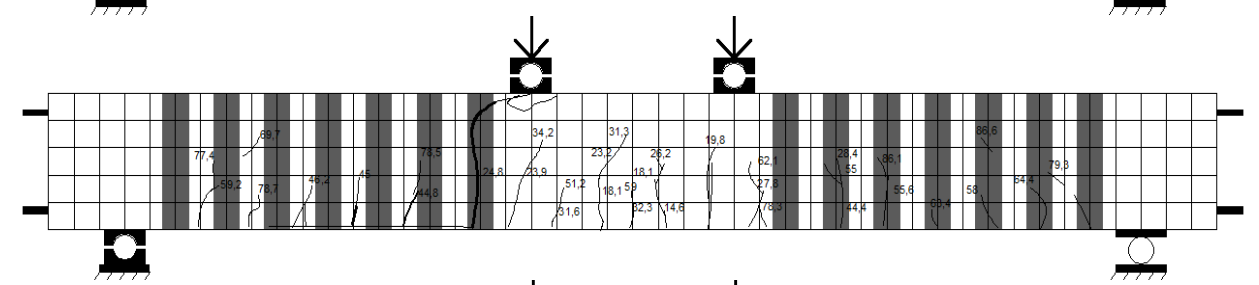

(f) BS-03V

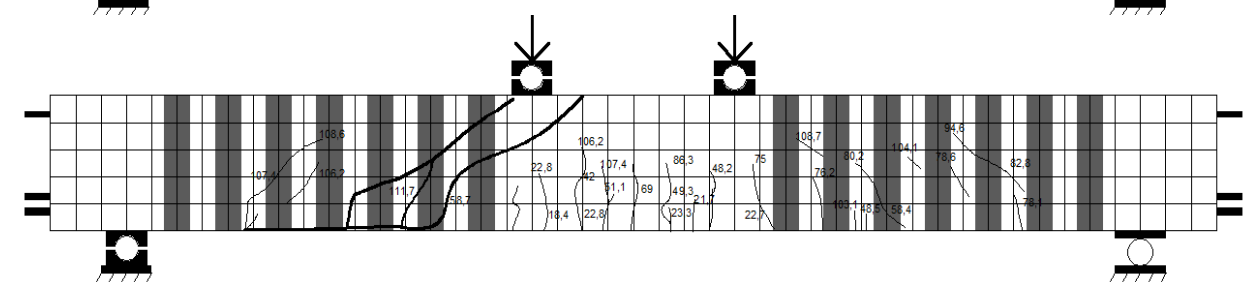

(g) BS-01D

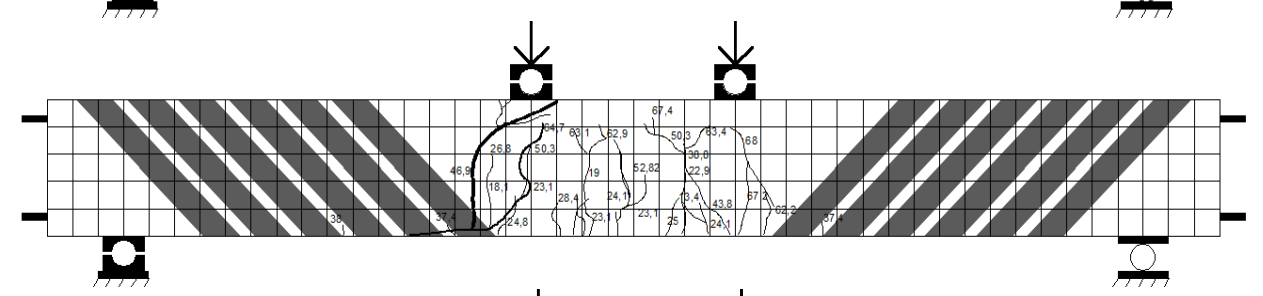

(h) BS-02D

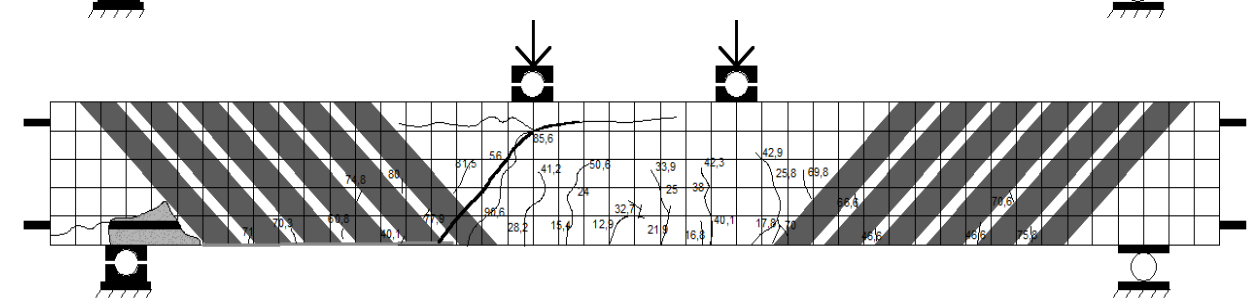

(i) BS-03D

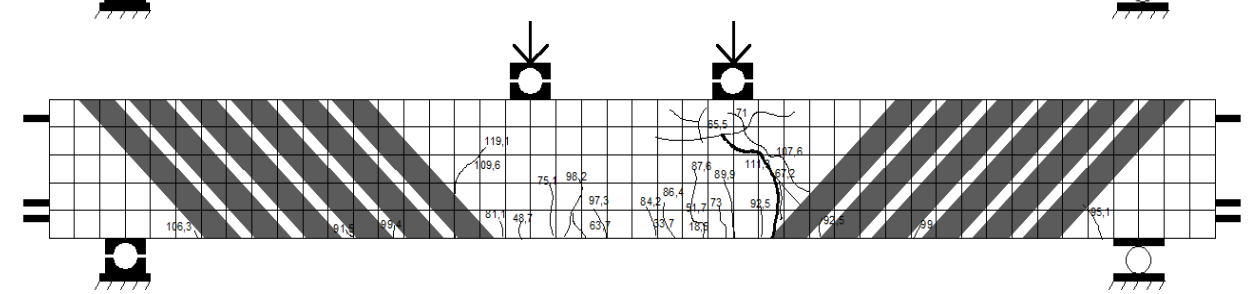

Fig. 7. Failure modes and cracking patterns of the beams. 


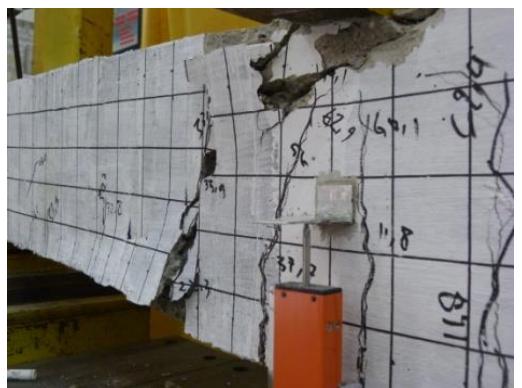

(a) BS-01V

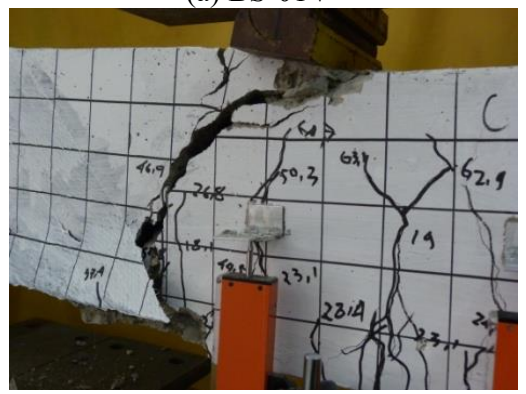

(d) BS-01D

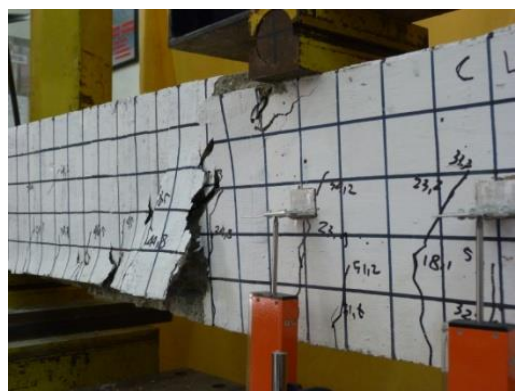

(b) BS-02V

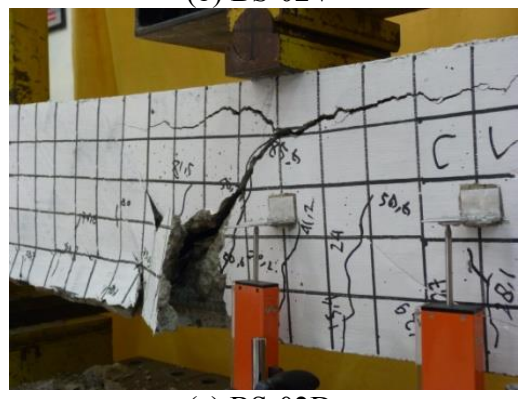

(e) BS-02D

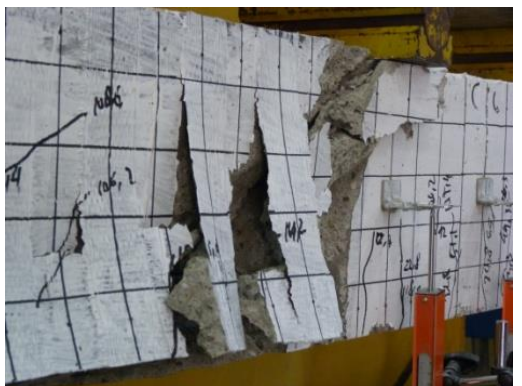

(c) BS-03V

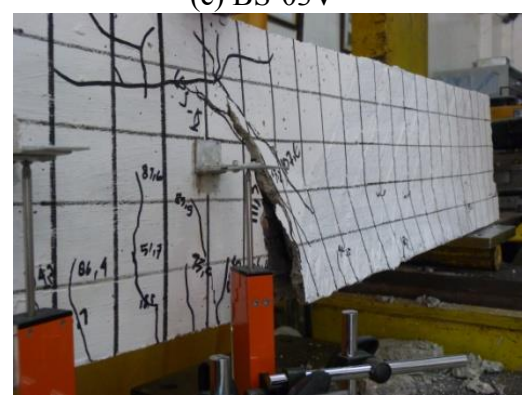

(f) BS-03D

Fig. 8. Parts of the strengthened beams after the occurrence of debonding failure.

\section{References}

1. E.G. Nawy, G.E. Neuwerth, and C.J. Phillips, Behavior of Fiber Glass Reinforced Concrete Beams, ASCE Journal of the Structural Division, 97(ST9), 2203-2215, (1971)

2. American Concrete Institute (ACI), Guide for the design and construction of externally bonded FRP systems for strengthening concrete structures (ACI 440.2R-17), Farmington Hills, MI, USA, (2017)

3. A. Khalifa, A. Belarbi, and A. Nanni, Shear performance of RC members strengthened with externally bonded FRP wraps, Proceedings of the 12th World Conference on Earthquake Engineering, Auckland, New Zealand, Paper 305, 1-10, (2000)

4. J.A.O. Barros, and S.J.E. Dias, Shear strengthening of reinforced concrete beams with laminate strips of CFRP, Proceedings of the International Conference Composites in Constructions, 289-294, (2003)

5. N.A. Hoult and J.M. Lees, Efficient CFRP strap configurations for the shear strengthening of reinforced concrete T-beams, ASCE Journal of Composites for Construction, 13(1), 45-52, (2009)

6. H. Galal, and A. Mofidi, Shear strengthening of RC T-beams using mechanically anchored unbonded dry carbon fiber sheets, ASCE Journal of Performance of Constructed Facilities, 24(1), 31-39, (2010)

7. A.I. Bukhari, L.R. Vollum, S. Ahmad, and J. Sagaseta, Shear strengthening of reinforced concrete beams with CFRP, Magazine of Concrete Research, 62(1), 65-77, (2010)

8. A. Mofidi and O. Chaallal, Shear strengthening of RC beams with externally bonded FRP composites: effect of strip-width-to-strip-spacing ratio, ASCE
Journal of Composites for Construction, 15(5), 732742, (2011)

9. S. Dirar, J. Lees, and C. Morley, Precracked reinforced concrete T-beams repaired in shear with bonded CFRP sheets, ACI Structural Journal, 109(2), 215-224, (2012)

10. R.Z. Al-Rousan and M.A. Issa, The effect of beam depth on the shear behavior of reinforced concrete beams externally strengthened with carbon fiberreinforced polymer composites, Advances in Structural Engineering, 19(11), 1769-1779, (2016)

11. A.S. Karzad, S. Al-Toubat, M. Maalej, and P. Estephane, Repair of reinforced concrete beams using carbon fiber reinforced polymer, MATEC Web of Conferences 120, 01008, (2017)

12. R.M. Foster, M. Brindley, J.M. Lees, and T.J. Ibell, Experimental investigation of reinforced concrete Tbeams strengthened in shear with externally bonded CFRP sheets, ASCE Journal of Composites for Construction, 21(2), 04016086, (2017)

13. ASTM C39/C39M-14, Standard Test Method for Compressive Strength of Cylindrical Concrete Specimens, ASTM International, (2014)

14. R. Park, and T. Paulay, Reinforced Concrete Structures, John Wiley, New York, (1975)

15. R. Thamrin, Analytical Prediction on Flexural Response of RC Beams Strengthened with Steel Plates, MATEC Web of Conf., 103, 02012, (2017).

16. J.B. Mander, M.J.N. Priestley, and R. Park, Theoretical Stress-Strain Model for Confined Concrete, Journal of Structural Engineering, 114(8), 1804-1826, (1988)

17. American Concrete Institute (ACI), Building Code Requirements for Structural Concrete (ACI 318-14) and Commentary (ACI 318R-14), Farmington Hills, Michigan, (2014) 